\title{
Chronic alcohol exposure increases ganglia endogenous morphine levels
}

Wei Zhu, Yiqing Li, Richard M. Kream, George B. Stefano

Neuroscience Research Institute, State University of New York - College at Old Westbury, Old Westbury, NY, USA

Submitted: 17 April 2010

Accepted: 3 June 2010

Arch Med Sci 2010; 6, 3: 316-320

DOI: 10.5114/aoms.2010.14249

Copyright ( 2010 Termedia \& Banach

\section{Abstract}

Introduction: We have previously demonstrated that alcohol has the ability to release low levels of endogenously expressed, chemically authentic, morphine from neural tissues.

Material and methods: Presently, we demonstrate that chronic exposure of Mytilus edulis pedal ganglia tissues maintained in organotypic culture to very concentrations of $1 \mathrm{mM}$ and $10 \mathrm{mM}$ ethanol induces a time dependent increase in both endogenous morphine and dopamine (DA) levels.

Results: Chronic incubation of $M$. edulis pedal ganglia with 3 concentrations of DA resulted in statistically significant elevations of cellular morphine levels, thereby confirming previous studies from our laboratory establishing DA as an essential precursor in the morphine biosynthetic pathway.

Conclusions: By understanding multiple debilitating effects of alcohol on "morphinergic" signaling, we may understand the ravages of neural processes associated with alcohol abuse and how its treatment may be made more effective.

Key words: endogenous morphine, dopamine, alcohol, ethanol, ganglia.

\section{Introduction}

The positive reinforcing effects of alcohol consumption are mediated through complex interactions between multiple CNS systems [1-11]. These systems appear to be functionally entrained within the A10 mesocorticalmesolimbic DA-ergic cell group. A10 DA neurons have also been implicated in the development of dependencies to relatively broad spectrum of addictive compounds including opiates, psychostimulants, and nicotine [12]. The neurochemical effects of alcohol on A10 neurons appear to be partially mediated via release of candidate neuromodulators/ neurotransmitters including endogenous opioid peptides, 5-HT, glutamate, GABA, and acetylcholine $[2,13]$. Mechanistically, these same neurochemical systems represent valid therapeutic targets to curb alcohol cravings and maintain abstinence in chronic abusers [14-17].

In particular, there appear to multiple levels of functional crosstalk between alcohol, opioid receptors, and A10 DA neurons [18, 19]. For example, the reinforcing behavioural properties of mu and delta opioid receptor selective agonists have been functionally mapped to specific regions of the nucleus accumbens (NAC) and prefrontal cortex [20, 21]. Several lines of evidence indicate alcohol-mediated disruption of normal
Corresponding author:

Dr. Wei Zhu

Neuroscience Research

Institute

SUNY College at Old

Westbury

P.O. Box 210, Old Westbury

NY 11568, USA

Phone: 001-516-876-2732

Fax: 001-516-876-2727

E-mail: zhuwei@sunynri.org 
opioid signaling mechanisms within A10 neurons. These include studies demonstrating direct effects of alcohol on the binding properties of opioid receptors, modulation of opioid peptide synthesis and secretion, and the formation of alcohol-derived isoquinoline condensation products [22]. The widespread clinical usage of the mu opioid receptor antagonist naltrexone for alcohol abuse provides strong confirmation of intimate functional relationships of alcohol, opiates, and A10 DA neurons [14].

In light of the discussion presented above, we have previously demonstrated that alcohol has the ability to release low levels of endogenously expressed, chemically authentic, morphine from various tissues, including those of neural origin [23, 24]. The potential importance of these observations may lie in their suggestive implications for the regulatory importance of cellular homeostasis maintained by ongoing "morphinergic" signaling events [25-27]. The critical importance of DA as an essential precursor in the morphine biosynthetic pathway lends further credence to these contentions [25-27]. More recent studies from our laboratory demonstrate that other substances of abuse (cocaine and nicotine) also appear to have the ability to release endogenous morphine from cells and at the same time promote compensatory synthesis of the alkaloid [23, 24, 28, 29].

In sum, previous work from our laboratory has demonstrated that multiple substances of abuse have the ability to enhance endogenous morphine processes at a common step, e.g., release from cellular stores, in invertebrate and human tissues $[23,24,28,30]$. In the present report we further demonstrate that chronic exposure of neural tissues to ethanol induces a time dependent increase in both endogenous morphine and DA levels. By understanding multiple debilitating effects of alcohol on "morphinergic" signaling, we may understand the ravages of neural processes associated with alcohol abuse and how its treatment may be made more effective.

\section{Material and methods}

\section{Tissue preparation and pharmacological treatments}

Mytilus edulis were collected from the local waters of Long Island Sound and maintained as previously described in detail [31]. Pooled pedal ganglia from 20 animals were separately incubated with $1 \mathrm{mM}$ or $10 \mathrm{mM}$ ethanol, or vehicle for $1 \mathrm{~h}, 2 \mathrm{~h}$, $6 \mathrm{~h}, 12 \mathrm{~h}$, and $24 \mathrm{~h}$. Ethanol and vehicle treated ganglia were harvested, washed, and extracted as described below. In an additional study, pooled pedal ganglia from 20 animals were separately incubated with DA at $10^{-7} \mathrm{M}, 10^{-6} \mathrm{M}$, and $10^{-5} \mathrm{M}$ for $18 \mathrm{~h}$. DA treated ganglia were harvested, washed, and extracted as described below.

\section{Extraction of treated pedal ganglia}

For morphine and DA analysis, pooled pedal ganglia samples were dissolved in $1 \mathrm{~N} \mathrm{HCl}$ and homogenized by sonication. Tissue homogenates were extracted with $5 \mathrm{ml}$ chloroform/isopropanol $9: 1$ for $5 \mathrm{~min}$ at $30^{\circ}$. Following centrifugation at $3000 \mathrm{rpm}$ for $15 \mathrm{~min}$, the upper aqueous phase was reserved for morphine and DA quantification and vacuum dried using a Centrivap Console (Labconco, Kansas City, Missouri). Dried extracts were dissolved in $1 \mathrm{ml} \mathrm{0.05 \%} \mathrm{trifluoroacetic} \mathrm{acid} \mathrm{(TFA),} \mathrm{clarified,} \mathrm{and}$ passed through activated Waters Sep-Pak Plus C-18 cartridges. Elution was achieved utilizing an H2O/CH3CN/TFA solution (89.5\% : 10\%: $0.05 \%$, $\mathrm{v} / \mathrm{v} / \mathrm{v})$. Eluted fractions were dried prior to morphine and DA analyses.

\section{RIA quantification of extracted morphine}

For analysis of morphine in extracted and dried fractions, we employed a commercially available RIA kit obtained from Diagnostic Products Corporation. The morphine RIA is a solid phase competitive binding analysis, whereby 1251 -labeled morphine competes for immobilized antibody binding sites with extracted morphine in the test sample (USA) [32-36]. The detection limit is $0.5 \mathrm{ng} / \mathrm{ml}$.

\section{Combined HPLC and electrochemical detection (ECD) of dopamine}

The combined HPLC-ECD analyses for DA quantification were performed with a Waters 626 pump (Waters, Milford, MA) and a C-18 Unijet microbore column (BAS). A flow splitter (BAS) was used to provide the low volumetric flow-rates required for the microbore column. The split ratio was 1/9. Operating the pump at $0.5 \mathrm{ml} / \mathrm{min}$, yielded a microbore column flow-rate of $50 \mu \mathrm{l} / \mathrm{min}$. The injection volume was $5 \mu$ l. Dopamine quantification was achieved via using amperometric detector LC-4C (BAS, West Lafayette, Indiana). The microbore column was coupled directly to the detector cell to minimize the dead volume. The electrochemical detection system used a glassy carbon-working electrode $(3 \mathrm{~mm}$ ) and a $0.02 \mathrm{~Hz}$ filter $(500 \mathrm{mV}$; range $10 \mathrm{nA})$. The cell volume was reduced by a $16-\mu \mathrm{m}$ gasket. The chromatographic system was controlled by Waters Millennium32 Chromatography Manager V3.2 software and the chromatograms were integrated with Chromatograph software (Waters).

\section{Statistical analysis}

A two-way ANOVA was used for statistical analysis of treated pedal ganglia tissues. Each 


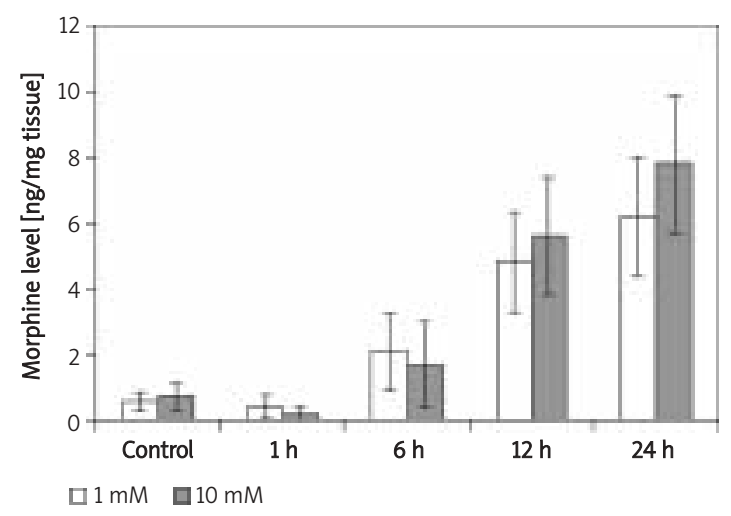

Figure 1. Chronic incubation of $M$. edulis pedal ganglia maintained in organotypic culture with $1 \mathrm{mM}$ or $10 \mathrm{mM}$ ethanol increases cellular morphine concentrations. Statistically significant elevations of cellular morphine levels of $1.74 \pm 0.73 \mathrm{ng} / \mathrm{mg}$, $5.26 \pm 0.68 \mathrm{ng} / \mathrm{mg}$, and $7.39 \pm 0.94 \mathrm{ng} / \mathrm{mg}$ were observed at $6 \mathrm{~h}, 12 \mathrm{~h}$, and $24 \mathrm{~h}$, respectively

experiment was performed 4 times. The mean value was combined with the mean value taken from 4 other replicates. The SEM represents the variation of the mean of the means.

\section{Results}

Chronic incubation of $M$. edulis pedal ganglia maintained in organotypic culture with very low concentrations of $1 \mathrm{mM}$ or $10 \mathrm{mM}$ ethanol for $1 \mathrm{~h}$, $6 \mathrm{~h}, 12 \mathrm{~h}$, and $24 \mathrm{~h}$, resulted in statistically significant elevations of cellular morphine levels (1.74 $\pm 0.73 \mathrm{ng} / \mathrm{mg}, \quad 5.26 \pm 0.68 \mathrm{ng} / \mathrm{mg}$, and $7.39 \pm 0.94 \mathrm{ng} / \mathrm{mg}$ ) for $6 \mathrm{~h}, 12 \mathrm{~h}$, and $24 \mathrm{~h}$ respectively (Figure 1). In effect, we observed apparent $200-400 \%$ increases in cellular morphine between $12 \mathrm{~h}$ and $24 \mathrm{~h}$ incubation with $1 \mathrm{mM}$ or $10 \mathrm{mM}$. These observations indicate that chronic

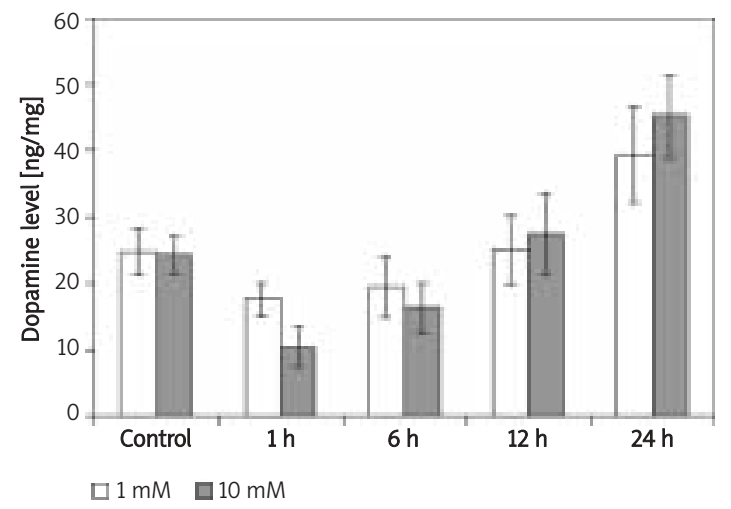

Figure 2. Chronic incubation of $M$. edulis pedal ganglia maintained in organotypic culture with $1 \mathrm{mM}$ or $10 \mathrm{mM}$ ethanol increases cellular DA concentrations. An apparent $100 \%$ increase in cellular DA concentrations after $24 \mathrm{~h}$ incubation with $1 \mathrm{mM}$ ethanol vs. control (17.53 $\pm 6.4 \mathrm{ng} / \mathrm{mg}$ vs. $38.75 \pm 7.36 \mathrm{ng} / \mathrm{mg}$, respectively) was observed incubation with very low concentrations of ethanol promote cellular biosynthetic mechanisms to increase endogenous morphine.

Chronic exposure of invertebrate neural ganglia to the same low concentrations of ethanol increased DA levels at the $24 \mathrm{~h}$ time point as well (Figure 2). As depicted in Figure 2, incubation of M. edulis pedal ganglia with $1 \mathrm{mM}$ or $10 \mathrm{mM}$ ethanol equivalent to $0.003 \% \mathrm{v} / \mathrm{v}$ and $0.03 \% \mathrm{v} / \mathrm{v}$, respectively, for $6 \mathrm{~h}, 12 \mathrm{~h}$, and $24 \mathrm{~h}$ resulted in a significant elevation of cellular DA levels at the $24 \mathrm{~h}$ time point $(19.33 \pm 5.18 \mathrm{ng} / \mathrm{mg}, 25.83 \pm 6.54 \mathrm{ng} / \mathrm{mg}$, and $38.75 \pm 7.36 \mathrm{ng} / \mathrm{mg}$ for $1 \mathrm{mM}$ ethanol at $6 \mathrm{~h}$, $12 \mathrm{~h}$, and $24 \mathrm{~h}$, respectively). We observed an apparent $100 \%$ increase in cellular DA concentrations after $24 \mathrm{hr}$ incubation with $1 \mathrm{mM}$ ethanol vs. control (17.53 $\pm 6.4 \mathrm{ng} / \mathrm{mg}$ vs. $38.75 \pm 7.36 \mathrm{ng} / \mathrm{mg}$, respectively). The $24 \mathrm{~h}$ increase in cellular DA concentration is consistent with the role of DA as an essential precursor in the morphine biosynthetic pathway [27].

Finally, chronic incubation of $M$. edulis pedal ganglia maintained in organotypic culture with 3 concentrations of DA at $10^{-7} \mathrm{M}, 10^{-6} \mathrm{M}$, and $10^{-5} \mathrm{M}$ for $18 \mathrm{~h}$, resulted in statistically significant elevations of cellular morphine levels: $4.2 \pm 1.7 \mathrm{ng} / \mathrm{mg}, 7.6 \pm 1.9 \mathrm{ng} / \mathrm{mg}, 9.3 \pm 2.5 \mathrm{ng} / \mathrm{mg}$, respectively (Figure 3 ). These observations confirm previous studies from our laboratory establishing DA as an essential precursor in the morphine biosynthetic pathway.

\section{Discussion}

In the present report we demonstrate that chronic exposure of $M$. edulis neural tissues maintained in organotypic culture to a very low concentration of $1 \mathrm{mM}$ ethanol equivalent to 0.003\% v/v ethanol induces a time dependent

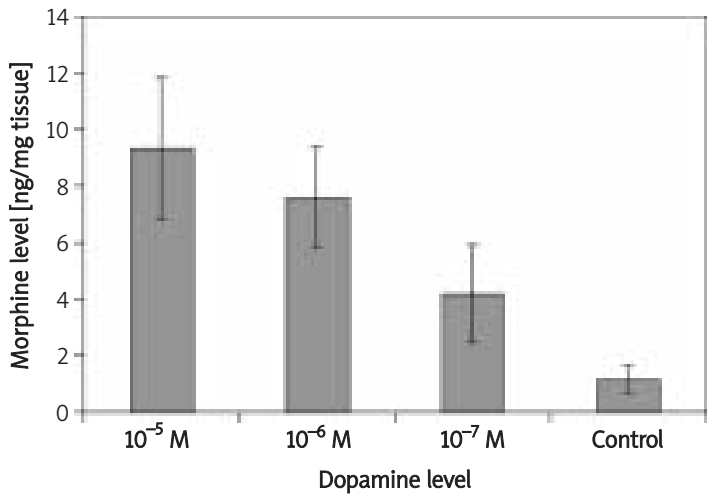

Figure 3. Chronic incubation of $M$. edulis pedal ganglia maintained in organotypic culture with 3 concentrations of DA at $10^{-7} \mathrm{M}, 10^{-6} \mathrm{M}$, and $10^{-5} \mathrm{M}$ for $18 \mathrm{~h}$, resulted in statistically significant elevations of cellular morphine levels (4.2 $\pm 1.7 \mathrm{ng} / \mathrm{mg}$, $7.6 \pm 1.9 \mathrm{ng} / \mathrm{mg}, 9.3 \pm 2.5 \mathrm{ng} / \mathrm{mg}$ ) 
increase in both endogenous morphine and DA levels. Interestingly, acute $1 \mathrm{hr}$ exposure to the same concentration of ethanol produces a marked reduction of endogenous morphine levels by $<50 \%$ vs. controls and is consistent with the ability of $1 \mathrm{mM}$ ethanol to promote evoked release of morphine into the cell culture medium, including those involving human white blood cells $[23,24]$. Furthermore, these experiments suggest that a portion of neural DA stores may be targeted for morphine biosynthesis and are open to physiological modulation, depending on the particular type of stimulus.

Previous studies have shown that CYP2D6 is one of the key enzymes for morphine biosynthesis in animals, including human $[26,37]$. In support of our current observations, others have shown that in post mortem analyses, brain tissues of chronic alcohol abusers express high levels of CYP2D6 [38]. Thus, a functional linkage between chronic alcohol exposure in vivo and endogenous morphine expression may be mediated via the increased expression of this key morphine biosynthetic enzyme [37].

Our overall testable hypothesis reciprocally linking endogenous morphine production and release to cellular processes necessary for homeostasis of DA-ergic signaling is supported by a gene expression/microarray study of human genes in primary cultures of human leukocytes exposed to pharmacological concentrations of morphine $\left(10^{-6} \mathrm{M}\right)$ [39]. Morphine effected differential changes in mRNA levels of candidate enzymes involved in DA/catecholamine and/or endogenous morphine synthesis. We observed an approximate $50 \%$ reduction in tyrosine hydroxylase, COMT, and CYP2D6 mRNA levels, as compared to control values. In contrast, levels of L-DOPA decarboxylase and DA $\beta$-hydroxylase (DDC and $\mathrm{DBH}$, respectively) mRNAs were relatively unchanged vs. control values, indicating a selective pharmacological effect of morphine on key enzyme activities involved in both endogenous morphine and DA expression in PMNs. Secondary validation of morphine-mediated changes in the gene expression/microarray analysis was provided by real-time Taqman RT-PCR of CYP2D6 mRNA expression in primary cultures of human PMNs treated with morphine. The RT-PCR analysis yielded equivalent reductions in cellular levels of CYP2D6 mRNA of approximately $50 \%$, thereby confirming the inhibitory effect of morphine on CYP2D6 mRNA expression monitored by gene expression/ microarray analysis. Furthermore, the study also demonstrated that the morphine action was mediated by NO, providing additional support for the functional linkage of endogenous morphine, the $\mu_{3}$, and cNOS activation.
In view of the reinforcing properties of alcohol in combination with the in vitro observations from our present study, the effects of alcohol on endogenous morphine and DA expression appear to be both time and dose dependent. Reciprocally, preclinical animal studies demonstrate dosedependent effects of administered morphine on the rate alcohol self administration [40, 41]. Finally, preclinical studies have led to the adoption of opioid antagonist therapies employing naltrexone for maintenance of alcohol abstinence in humans [42].

\section{References}

1. Koob GF, Roberts AJ, Schulteis G, et al. Neurocircuitry targets in ethanol reward and dependence. Alcohol Clin Exp Res 1998; 22: 3-9.

2. Valenzuela CF. Alcohol and neurotransmitter interactions. Alcohol Health Res World 1997; 21: 144-8.

3. Kream RM, Stefano GB. Homeopathic ethanol. Med Sci Monit 2008; 14: SC11-3.

4. Zhu W, Esch T, Kream RM, Stefano GB. Converging cellular processes for substances of abuse: endogenous morphine. Neuro Endocrinol Lett 2008; 29: 63-6.

5. Stefano GB, Stefano JM, Esch T. Anticipatory stress response: a significant commonality in stress, relaxation, pleasure and love responses. Med Sci Monit 2008; 14: RA17-21.

6. Kream RM, Stefano GB. Endogenous morphine and nitric oxide coupled regulation of mitochondrial processes. Med Sci Monit 2009; 15: RA263-8.

7. Stefano GB, Esch T, Kream RM. Xenobiotic perturbation of endogenous morphine signaling: paradoxical opiate hyperalgesia. Med Sci Monit 2009; 15: RA107-10.

8. Stefano GB, Kream RM, Esch T. Revisiting tolerance from the endogenous morphine perspective. Med Sci Monit 2009; 15: RA189-98.

9. Naha N, Lee HY, Naser MI, Park TJ, Kim SH, Kim MO. Ethanol inhibited apoptosis-related RNA binding protein, Napor-3 gene expression in the prenatal rat brain. Med Sci Monit 2009; 15: BR6-12.

10. Yokoyama H, Hirose H, Saito I. Two types of unsafe drinker judged to have metabolic syndrome: typical metabolic syndrome or alcohol-related syndrome? Med Sci Monit 2009; 15: H57-64.

11. Gu Y, Yun L, Tian Y, Hu Z. Association between COMT gene and Chinese male schizophrenic patients with violent behavior. Med Sci Monit 2009; 15: CR484-89.

12. Pierce RC, Kumaresan V. The mesolimbic dopamine system: the final common pathway for the reinforcing effect of drugs of abuse? Neurosci Biobehav Rev 2006; 30: 215-38.

13. Mukherjee S, Das SK, Vaidyanathan K, Vasudevan DM. Consequences of alcohol consumption on neurotransmitters - an overview. Curr Neurovasc Res 2008; 5 : 266-72.

14. Ray LA, Chin PF, Miotto K. Naltrexone for the treatment of alcoholism: clinical findings, mechanisms of action, and pharmacogenetics. CNS Neurol Disord Drug Targets 2010; 9: 13-22.

15. Soyka M, Rosner S. Opioid antagonists for pharmacological treatment of alcohol dependence - a critical review. Curr Drug Abuse Rev 2008; 1: 280-91.

16. Garbutt JC, West SL, Carey TS, Lohr KN, Crews FT. Pharmacological treatment of alcohol dependence: a review of the evidence. JAMA 1999; 281: 1318-25. 
17. Herz A. Opioid reward mechanisms: a key role in drug abuse? Can J Physiol Pharmacol 1998; 76: 252-8.

18. Lam MP, Marinelli PW, Bai L, Gianoulakis C. Effects of acute ethanol on opioid peptide release in the central amygdala: an in vivo microdialysis study. Psychopharmacology (Berl) 2008; 201: 261-71.

19. Marinelli PW, Funk D, Juzytsch W, et al. Opioid receptors in the basolateral amygdala but not dorsal hippocampus mediate context-induced alcohol seeking. Behav Brain Res 2010; 211: 58-63.

20. Herz A. Endogenous opioid systems and alcohol addiction. Psychopharmacology (Berl) 1997; 129: 99-111.

21. Russo SJ, Dietz DM, Dumitriu D, Morrison JH, Malenka RC, Nestler EJ. The addicted synapse: mechanisms of synaptic and structural plasticity in nucleus accumbens. Trends Neurosci 2010; Mar 4. [Epub ahead of print].

22. Davis VE, Walsh MJ. Alcohol, amines, and alkaloids: a possible biochemical basis for alcohol addiction. Science 1970; 167: 1005-7.

23. Zhu W, Mantione KJ, Casares FM, et al. Alcohol-, nicotine, and cocaine-evoked release of morphine from invertebrate ganglia: model system for screening drugs of abuse. Med Sci Monit 2006; 12: BR155-61.

24. Zhu W, Mantione K, Kream RM, Stefano GB. Alcohol-, nicotine-, and cocaine-evoked release of morphine from human white blood cells: substances of abuse actions converge on endogenous morphine release. Med Sci Monit 2006; 12: BR350-4.

25. Zhu W, Mantione KJ, Shen L, et al. Tyrosine and tyramine increase endogenous ganglionic morphine and dopamine levels in vitro and in vivo: CYP2D6 and tyrosine hydroxylase modulation demonstrates a dopamine coupling. Med Sci Monit 2005; 11: BR397-404.

26. Zhu W, Cadet P, Baggerman G, Mantione KJ, Stefano GB. Human white blood cells synthesize morphine: CYP2D6 modulation. J Immunol 2005; 175: 7357-62.

27. Kream RM, Stefano GB. De novo biosynthesis of morphine in animal cells: an evidence-based model. Med Sci Monit 2006; 12: RA207-19.

28. Zhu W, Mantione KJ, Casares FM, Sheehan MH, Kream RM, Stefano GB. Cholinergic regulation of endogenous morphine release from lobster nerve cord. Med Sci Monit 2006; 12: BR295-301.

29. Stefano GB, Bianchi E, Guarna M, et al. Nicotine, alcohol and cocaine coupling to reward processes via endogenous morphine signaling: the dopamine-morphine hypothesis. Med Sci Monit 2007; 13: RA91-102.

30. Zhu W, Mantione KJ, Shen L, Lee B, Stefano GB. Norlaudanosoline and nicotine increase endogenous ganglionic morphine levels: nicotine addiction. Cell Mol Neurobiol 2006; 26: 1037-45.

31. Stefano GB, Teoh MB, Grant A, Reid C, Teoh H, Hughes TK. Electric field exposure activates immunocytes: evidence for calcium dependency. Electro-Magnetobiol 1994; 13 : 123-36.

32. Zhu W, Ma Y, Cadet P, et al. Presence of reticuline in rat brain: a pathway for morphine biosynthesis. Mol Brain Res 2003; 117: 83-90.

33. Zhu W, Baggerman G, Goumon Y, Casares F, Brownawell B, Stefano GB. Presence of morphine and morphine6-glucuronide in the marine mollusk Mytilus edulis ganglia determined by GC/MS and Q-TOF-MS. Starvation increases opiate alkaloid levels. Brain Res Mol Brain Res 2001; 88: 155-60

34. Zhu W, Ma Y, Stefano GB. Presence of isoquinoline alkaloids in molluscan ganglia. Neuroendocrinol Lett 2002 23: 329-34.
35. Zhu W, Stefano GB. Reticuline exposure to invertebrate ganglia increases endogenous morphine levels. Neuro Endocrinol Lett 2004; 25: 323-30.

36. Zhu W, Baggerman G, Goumon Y, Zenk MH, Stefano GB. Identification of morphine and morphine-6-glucuronide in the adrenal medullary chromaffin PC-12 cell line by nano electrospray ionization double quadrupole orthogonal acceleration time of flight mass spectrometry. Eur J Mass Spect 2001; 7: 25-8.

37. Zhu W. CYP2D6: a key enzyme in morphine synthesis in animals. Med Sci Monit 2008; 14: SC15-SC18.

38. Miksys S, Rao Y, Hoffmann E, Mash DC, Tyndale RF. Regional and cellular expression of CYP2D6 in human brain: higher levels in alcoholics. J Neurochem 2002; 82: 1376-87.

39. Mantione KJ, Cadet P, Zhu W, et al. Endogenous morphine signaling via nitric oxide regulates the expression of CYP2D6 and COMT: autocrine/paracrine feedback inhibition. Addict Biol 2008; 13: 118-23.

40. Linseman MA. Central vs. peripheral mediation of opioid effects on alcohol consumption in free-feeding rats. Pharmacol Biochem Behav 1989; 33: 407-13.

41. Kornet M, van Vlaardingen JA, Goosen C, Van Ree JM. Low doses of morphine reduce voluntary alcohol consumption in rhesus monkeys. Eur Neuropsychopharmacol 1992; 2: 73-86.

42. Coonfield DL, Hill KG, Kaczmarek HJ, Ferraro FM III, Kiefer SW. Low doses of naltrexone reduce palatability and consumption of ethanol in outbred rats. Alcohol 2002; 26: 43-7. 